\title{
Faktor-Faktor Yang Memengaruhi Kinerja Sistem Informasi Akuntansi Dengan Pendidikan Dan Pelatihan Sebagai Variabel Moderasi Pada PT. Bukit Megagriya Makmur
}

\section{Dyah Ayu Safitri ${ }^{a}$, Muhammad Firdaus $^{b}$, Nurshadrina Kartika Sari ${ }^{c}$}

\author{
${ }^{a}$ STIE Mandala, dyahayusafitri47@gmail.com \\ ${ }^{b}$ STIE Mandala,firdaus@stie-mandala.ac.id \\ ${ }^{c}$ STIE Mandala, shadrina.kartika@stie-mandala.ac.id
}

\section{N F O A R T I K E L}

\section{Riwayat Artikel:}

Artikel Dikirim

Revisi

Artikel Diterima

\section{Keywords:}

User participation, user capabilities, top management support, education and training, and accounting information system performance.

\section{Kata Kunci:}

Partisipasi pengguna, kemampuan pengguna, dukungan manajemen puncak, pendidikan dan pelatihan, dan kinerja sistem informasi akuntansi.

\begin{abstract}
A B S T R A C T
This study was conducted to determine the effect of user participation, user ability, and top management support on the performance of accounting information systems through education and training as moderating variables at PT. Megagriya Makmur Hill. This research uses classical assumption test, data quality test, descriptive statistical test, multiple linear regression, Moderated Regression Analysis test, and hypothesis testing. The results of the study show that user participation, user capabilities, top management support, have an effect on the performance of accounting information systems. When moderation occurs, education and training are not able to moderate user participation and top management support on accounting information system performance, while education and training are able to moderate users' ability to accounting information system performance.
\end{abstract}

\section{A B S T R A K}

Penelitian ini bertujuan untuk mengetahui pengaruh partisipasi pengguna, kemampuan pengguna, dan dukungan manajemen puncak, terhadap kinerja system informasi akuntansi melalui pendidikan dan pelatihan sebagai variabel moderasi pada PT. Bukit Megagriya Makmur. Data yang digunakan dalam penelitian ini berupa data primer yang dikumpulkan dari penyebaran kuesioner pada staf kantor dan lapangan PT. Bukit Megagriya Makmur. Pengolahan data menggunakan bantuan alat analisis SPSS 26. Penelitian ini menggunakan metode analisis data uji kualitas data, uji regresi linear berganda, uji Moderated Regression Analysis, uji asumsi klasik dan uji hipotesis. Hasil penelitian menunjukkan bahwa partisipasi pengguna, kemampuan pengguna, dan dukungan manajemen puncak berpengaruh positif dan signifakan terhadap kinerja sistem informasi akuntansi. Partipasi pengguna tidak berpengaruh 
terhadap kinerja sistem informasi akuntansimelalui pendidikan dan pelatihan sebagai variabel moderasi. Kemampuan pengguna berpengaruh positif dan signifikan terhadap kine rja sistem informasi akuntansi melalui pendidikan dan pelatihan sebagai variabel moderasi. Dukungan manajemen puncak tidak berpengaruh terhadap kinerja sistem informasi akuntansi melalui pendidikan dan pelatihan sebagai variabel moderasi.

\section{PENDAHULUAN}

Perkembangan ilmu teknologi saat ini baik di Indonesia maupun luar negeri berkembang dengan cepat dan semakin canggih. Perkembangan teknologi saat ini tentu mendorong perusahaan untuk meningkatkan pelayanan dan kualitas kinerja. Salah satu perkembangan teknologi dalam perusahaan adalah sistem informasi akuntansi. Menurut Susanto (2008) sistem informasi akuntansi adalah gabungan dari sub sistem baik fisik maupun non fisik yang saling berhubungan dan saling bekerjasama satu sama lain untuk mengolah data transaksi yang berhubungan dengan masalah keuangan menjadi sebuah informasi akuntansi.

Menurut Irawan (2000:11) kinerja merupakan sesuatu yang dapat diraih, yang merupakan hasil kerja dan memiliki hasil nyata yang dapat diamati dan dapat diukur. Salah satu contoh sistem informasi akuntansi yang digunakan oleh perusahaan adalah aplikasi.

PT. Bukit Megagriya Makmur merupakan salah satu developer di Jember yang menggunakan SIA. SIA yang digunakan berupa aplikasi yang bernama SiKasep. SiKasep merupakan aplikasi yang dapat digunakan oleh calon debitur untuk melakukan proses pengajuan KPR (Kredit Pemilikan Rumah) dengan tujuan untuk mengetahui apakah sudah lolos subsidi checking. Penerapan SIA dalam perusahaan ini mendapat kendala pada penggunaan aplikasi SiKasep.

Permasalahan tersebut berupa adanya beberapa pengguna yang masih kesulitan dalam pengoperasian aplikasi, adanya kelalaian pengguna ketika menginput data dan kurangnya partisipasi pengguna.

Dari permasalahan tersebut tentu ada beberapa faktor-faktor yang dapat memengaruhi kinerja SIA. Menurut Soegiharto (2001) dan Jen (2002) ada beberapa faktor yang memengaruhi kinerja SIA yang terdiri dari "keterlibatan pengguna, kemampuan pengguna, ukuran organisasi, dukungan manajemen puncak, formalisasi pengembangan sistem informasi, program pendidikan dan pelatihan pengguna, keberadaan dewan pengarah sistem informasi, dan lokasi departemen sistem informasi”.

Penelitian ini menggunakan variabel independen partisipasi pengguna, kemampuan pengguna dan dukungan manajemen puncak. Menurut Rusmiati (2012) pengembangan SIA akan berhasil dengan adanya partisipasi dari pengguna. Menurut Suroto (2017) partisipasi pengguna berpengaruh positif dan signifikan terhadap kinerja SIA. Sedangkan menurut Yulianto (2016) keterlibatan pengguna tidak berpengaruh signifikan terhadap kinerja pengguna SIA.

Ada faktor lain yang memengaruhi kinerja SIA yaitu kemampuan pengguna. Menurut 
Puspitasari dan Juliarsa (2017) kemampuan pengguna berpengaruh positif dan signifikan terhadap kinerja SIA. Sedangkan menurut Prabowo (2014) dalam penelitianya menyatakan kemampuan pengguna tidak berpengaruh positif secara signifikan terhadap kinerja SIA.

Faktor lain yang memengaruhi kinerja SIA adalah dukungan manajemen puncak. Berdasarkan Muliana, dkk (2017) dukungan manajemen puncak berpengaruh positif terhadap kinerja sistem informasi akuntansi. Sedangkan Yulianto (2016) menyatakan dukungan manajemen puncak tidak berpengaruh terhadap kinerja SIA.

Terdapat ketidakkonsistenan pada penelitian sebelumnya terhadap variabel partisipasi pengguna, kemampuan pengguna dan dukungan manajemen puncak. Penelitian yang dilakukan oleh Murray (1990) menyatakan bahwa untuk menyesuaikan hasil yang saling betentangan dapat dilakukan dengan meneliti berbagai faktor kondisional yaitu dengan cara menggunakan variabel moderasi.

Penelitian terdahulu yang dijadikan rujukan dalam penelitian ini adalah Puspitasari dan Juliarsa (2017) dengan hasil penelitian, keterlibatan pemakai, kemampuan teknik personal berpengaruh positif dan signifikan pada kinerja SIA, Pendidikan dan pelatihan tidak mampu memoderasi pengaruh keterlibatan pemakai pada kinerja SIA, dan pendidikan dan pelatihan mampu memoderasi pengaruh kemampuan teknik personal pada kinerja SIA.

Indrianto dan Saputra (2020) yang menyatakan menyatakan kemampuan pengguna, partisipasi pengguna berpengaruh positif dan signifikan terhadap efektivitas penggunaan SIA. Pelatihan memperkuat pengaruh kemampuan teknik personal dan keterlibatan pemakai pada efektifitas penggunaan SIA.

Penelitian ini berbeda dengan penelitian sebelumnya, dimana penelitian ini dilakukan pada PT. Bukit Megagriya Makmur dengan menggunakan uji MRA nilai selisih mutlak. Penelitian ini dibatasi dengan penggunaan SIA pada periode juni 2020-2021. Penelitian ini bertujuan untuk Untuk mengetahui pengaruh partisipasi pengguna, kemampuan pengguna, dukungan manajemen puncak terhadap kinerja SIA, dan untuk mengetahui pengaruh partisipasi pengguna, kemampuan pengguna, dukungan manajemen puncak terhadap kinerja SIA melalui pendidikan dan pelatihan sebagai variabel moderasi.

\section{KAJIAN PUSTAKA}

\section{Sistem Informasi Akuntansi}

Menurut Susanto (2008:72) sistem informasi akuntansi adalah gabungan dari sub sistem baik fisik maupun non fisik yang saling berhubungan dan saling bekerjasama satu sama lain untuk mengolah data transaksi yang berhubungan dengan masalah keuangan menjadi sebuah informasi akuntansi.

\section{Kinerja Sistem Informasi Akuntansi}

Menurut Irawan (2000:11) kinerja merupakan sesuatu yang dapat diraih, yang merupakan hasil kerja 
dan memiliki hasil nyata yang dapat diamati dan dapat diukur. Kinerja sistem informasi akuntansi yang baik adalah yang mampu memenuhi kebutuhan pengguna sistem informasi akuntansi, sehingga dapat membantu pengguna sistem menyelesaikan pekerjaannya (Srimindarti dan Elen, 2012).

\section{Kemampuan pengguna}

Kemampuan pengguna merupakan keahlian yang dimiliki oleh seseorang yang diperoleh dari pengalaman dan dari pendidikan atau pelatihan yang pernah diikuti sehingga dapat meningkatkan kepuasannya untuk menggunakan SIA yang diterapkan oleh suatu organisasi (Suryawarman dan Sari, 2013).

\section{Dukungan Manajemen Puncak}

Menurut Hashmi (2004) dukungan manajemen puncak adalah pihak yang bertanggung jawab atas penyediaan pedoman umum bagi kegiatan sistem informasi. Dukungan yang diberikan oleh manajemen puncak tersebut bagi sistem informasi perusahaan dapat menjadi salah satu faktor yang sangat penting dalam menentukan keberhasilan seluruh kegiatan yang berkaitan dengan sistem informasi.

\section{Pendidikan dan Pelatihan}

Menurut Sumarsono (2009) pendidikan dan pelatihan merupakan salah satu faktor yang sangat penting dalam pengembangan Sumber Daya Manusia. Karena pendidikan dan pelatihan tidak hanya menambah pengetahuan, akan tetapi juga dapat meningkatkan keterampilan dalam bekerja, karena dengan hal itu dapat meningkatkan produktivitas kerja.

\section{METODA PENELITIAN}

\section{Gambaran Singkat Objek Penelitian}

Penelitian dilakukan di PT.Bukit Megagriya Makmur dengan proyek perumahan bernama Taman Gading yang terletak di Jl. Basuki Rahmat 137 Jember.

\section{Populasi}

Populasi dalam penelitian ini adalah karyawan yang menggunakan SIA yaitu staf kantor dan bagian lapangan sebanyak 35 karyawan.

\section{Sampel}

Penelitian ini menggunakan teknik purposive sampling dengan kriteria :

1) Karyawan PT. Bukit Megagriya Makmur yang berhubungan dengan SIA perusahaan.

2) Pengambilan sampel pada karyawan staf kantor dan lapangan

Berdasarkan kriteria di atas, maka sampel yang akan digunakan sebanyak 32 karyawan yang terdiri staf kantor dan bagian lapangan. 


\section{Jenis Penelitian}

Jenis Penelitian ini adalah kuantitatif dengan menggunakan data primer dan data sekunder.

\section{Definisi Operasional Variabel Penelitian}

Definisi operasional variabel dari masing-masing variabel dalam penelitian ini adalah sebagai berikut:

Tabel 1. Alat Ukur Penelitian

\begin{tabular}{|c|c|c|}
\hline No & Variabel & Indikator \\
\hline 1 & $\begin{array}{l}\text { Kinerja } \quad \text { Sistem Informasi } \\
\text { Akuntansi Soegiharto (2001) }\end{array}$ & $\begin{array}{l}\text { Informasi yang dihasilkan sesuai dengan } \\
\text { kebutuhan pengguna, Keakuratan informasi, } \\
\text { Kemudahan akses, Kemudahan memahami, } \\
\text { Kemudahan penggunaan }\end{array}$ \\
\hline 2 & $\begin{array}{l}\text { Partisipasi Pengguna }\left(X_{1}\right) \\
\text { Susanto (2013) }\end{array}$ & $\begin{array}{l}\text { Hubungan, Wawasan, Tanggung Jawab, Waktu, } \\
\text { Keinginan pengguna, Nilai, kepuasan, dukungan, } \\
\text { Biaya }\end{array}$ \\
\hline 3 & $\begin{array}{l}\text { Kemampuan Pengguna }\left(X_{2}\right) \\
\text { Robbins dan Judge (2007) }\end{array}$ & $\begin{array}{l}\text { Pengetahuan (Knowladge), Kemampuan (Ability), } \\
\text { Keahlian (Skills) }\end{array}$ \\
\hline 4 & $\begin{array}{l}\text { Dukungan Manajemen Puncak }\left(X_{3}\right) \\
\text { Lee dan Kim (1992) dalam Komara } \\
(2005)\end{array}$ & $\begin{array}{l}\text { 1. Pemahaman manajemen puncak terhadap } \\
\text { sistem komputer } \\
\text { a. Kemampuan manajer menggunakan } \\
\text { komputer } \\
\text { 2. Tingkat minat, dukungan dan wawasan tentang } \\
\text { sistem informasi } \\
\text { a. Perhatian terhadap kinerja sistem } \\
\text { informasi } \\
\text { b. Rating pemakaian sistem informasi dari } \\
\text { bagian pengguna }\end{array}$ \\
\hline 5 & $\begin{array}{l}\text { Pendidikan Dan Pelatihan (Z) } \\
\text { Jogiyanto (2009) }\end{array}$ & $\begin{array}{l}\text { Kualitas pendidikan dan pelatihan, Prosedur } \\
\text { sistematis, Keterampilan teknis, Mempelajari } \\
\text { pengetahuan, Mengutamakaan praktek dari pada } \\
\text { teori }\end{array}$ \\
\hline
\end{tabular}

\section{Metode Analisa Data}

Uji Asumsi Klasik

Uji Normalitas 
Kriteria pengujian uji normalitas adalah sebagai berikut :

1) Nilai probabilitas (sig) $>0,05$, maka data berdistribusi normal.

2) Nilai probabilitas (sig) $<0,05$, maka data tidak berdistribusi normal.

\section{Uji Multikolinieritas}

Nilai yang umum digunakan untuk menunjukkan adanya multikolinearitas adalah jika nilai tolerance $\leq 0.10$ atau sama dengan nilai VIF $\geq 10$ dapat dikatakan dalam data tersebut terdapat multikolinearitas (Ghozali, 2018).

\section{Uji Heteroskedastisitas}

Model regresi yang baik adalah yang homoskedastisitas atau tidak terjadi heteroskedastisitas. Apabila nilai probabilitas $($ sig) $>$ dari 0,05 maka tidak terjadi heteroskedastisitas.

\section{Uji Kualitas Data}

\section{Uji Validitas}

Kriteria uji validitas adalah sebagai berikut :

1) Jika nilai thitung > t tabel maka dikatakan valid.

2) Jika nilai t hitung < t tabel maka dikatakan tidak valid.

\section{Uji Reliabilitas}

Suatu variabel dikatakan reliabel jika nilai Cronbach Alpha >0.60 (Nunnally, 1960 dalam Ghozali 2007).

\section{Statistik Deskriptif}

Pada penelitian ini akan melihat nilai rata-rata, standar deviasi, maksimum dan minimum dari variabel partispasi pengguna (X1), kemampuan pengguna (X2), dukungan manajemen puncak (X3), pendidikan dan pelatihan (Z), dan kinerja SIA (Y).

\section{Metode Regresi Linear Berganda}

Model persamaan regresi linear berganda dalam penelitian ini sebagai berikut: $\mathrm{Y}=\mathrm{a}+\mathrm{b} 1 \mathrm{X} 1+\mathrm{b} 2 \mathrm{X} 2$ $+\mathrm{b} 3 \mathrm{X} 3+\mathrm{e} 1$

Keterangan:

$\mathrm{Y}$

A : Konstanta

b1b2b3 : Koefesien linier berganda

$\mathrm{X} 1 \quad$ : Partisipasi pengguna

$\mathrm{X} 2 \quad$ : Kemampuan pengguna

X3 : Dukungan manajemen puncak

e1 : Standar error 


\section{Uji Moderated Regression Analysis (MRA)}

Persamaan yang digunakan dalam penelitian ini menggunakan metode nilai selisih mutlak adalah sebagai berikut :

$\mathrm{Y}=\alpha+\mathrm{b}_{1} \mathrm{X}_{1}+\mathrm{b}_{2} \mathrm{X}_{2}+\mathrm{b}_{3} \mathrm{X} 3+\mathrm{b} 4 \mathrm{Z}+\mathrm{b} 5\left|\mathrm{X}_{1}-\mathrm{Z}\right|+\mathrm{b} 6|\mathrm{X} 2-\mathrm{Z}|+\mathrm{b} 7|\mathrm{X} 3-\mathrm{Z}|+\mathrm{e}$

Dimana untuk persamaan diatas, variabel $X 1, X 2, X 3$ dan $Z$ di standardized.

Keterangan :

Y : Kinerja sistem informasi akuntansi

A : Konstanta

b1 - b7 : Koefesien linier berganda

$\mathrm{X} 1 \quad$ : Partisipasi pengguna

X2 : Kemampuan pengguna

X3 : Dukungan manajemen puncak

$\mathrm{Z} \quad$ : Pendidikan dan Pelatihan

$\left|X_{1}-Z\right| \quad$ : Merupakan interaksi yang diukur dengan nilai absolut perbedaan antara $\mathrm{X} 1$ dan $\mathrm{Z}$

$|\mathrm{X} 2-\mathrm{Z}| \quad$ : Merupakan interaksi yang diukur dengan nilai absolut perbedaan antara $\mathrm{X} 2$ dan $\mathrm{Z}$

$|\mathrm{X} 3-\mathrm{Z}| \quad$ : Merupakan interaksi yang diukur dengan nilai absolut perbedaan antara

$\mathrm{X} 3$ dan $\mathrm{Z}$

E : Standar error

untuk membuktikan apakah variabel moderasi yang digunakan benar memoderasi variabel

X terhadap Y maka perlu diketahui kriteria sebagai berikut :

Tabel 2 Kriteria Penentuan Variabel Moderating

\begin{tabular}{|l|l|l|}
\hline No. & Tipe Moderasi & Koefisien \\
\hline 1. & Pure Moderasi & b1 Tidak Signifikan b2 Signifikan \\
\hline 2 & Quasi Moderasi & b1 Signifikan b2 Signifikan \\
\hline 3. & Homologiser Moderasi (bukan moderasi) & $\begin{array}{l}\text { b1 Tidak Signifikan b2 Tidak } \\
\text { Signifikan }\end{array}$ \\
\hline 4. & Prediktor & b1 Signifikan b2 Tidak Signifikan \\
\hline
\end{tabular}

Keterangan :

b1 : Variabel pendidikan dan pelatihan.

b2 : Variabel interaksi antara masing-masing variabel independen 
Pada uji MRA ini dilakukan 2 tahap regresi untuk mengetahui peranan variabel pendidikan dan pelatihan terhadap variabel independen

- Tahap 1 tanpa interaksi, persamaan yang digunakan sebagai berikut :

$\mathrm{Y}=\alpha+\mathrm{b}_{1} \mathrm{X}_{1}+\mathrm{b}_{2} \mathrm{Z}+\mathrm{e}$

- Tahap 2 dengan interaksi, persamaan yang digunakan sebagai berikut:

$\mathrm{Y}=\alpha+\mathrm{b}_{1} \mathrm{X}_{1}+\mathrm{b}_{2} \mathrm{X}_{2}+\mathrm{b}_{3} \mathrm{X} 3+\mathrm{b} 4 \mathrm{Z}+\mathrm{b} 5\left|\mathrm{X}_{1}-\mathrm{Z}\right|+\mathrm{b} 6|\mathrm{X} 2-\mathrm{Z}|+\mathrm{b} 7|\mathrm{X} 3-\mathrm{Z}|+\mathrm{e}$

\section{PEMBAHASAN}

\section{Pengaruh partisipasi pengguna terhadap kinerja SIA}

Hasil analisis penelitian menunjukkan bahwa partisipasi pengguna berpengaruh positif dan signifikan terhadap kinerja sistem informasi akuntansi. Hasil analisis regresi linear berganda menunjukan nilai signifikansi partisipasi pengguna sebesar 0,013. Hasil ini sesuai dengan penelitian Muliana,dkk (2017), Puspitasari dan juliarsa (2017) yang menyatakan partisipasi pengguna berpengaruh positif dan signifikan terhadap kinerja SIA.

Hasil ini juga diperkuat dengan hasil uji statistik deskriptif yang menunjukkan nilai mean > minimum yang berarti bahwa responden PT. Bukit Megagriya Makmur menyadari akan pentingnya partisipasi pengguna dalam penggunaan SIA pada perusahaan. Hal ini bahwa semakin tinggi partisipasi pengguna, maka akan semakin tinggi pula kinerja SIA yang akan dihasilkan pada perusahaan.

\section{Pengaruh Kemampuan Pengguna Terhadap Kinerja SIA}

Hasil analisis penelitian menunjukkan bahwa kemampuan pengguna berpengaruh positif dan signifikan terhadap kinerja sistem informasi akuntansi. Hasil analisis regresi linear berganda menunjukan nilai signifikansi kemampuan pengguna sebesar 0,043<0,05. Hasil ini sesuai dengan penelitian Septianingrum (2014), dan Muliana, dkk (2017) yang menyatakan kemampuan pengguna berpengaruh positif dan signifikan terhadap kinerja sistem informasi akuntansi.

Berdasarkan hasil analisis deskriptif variabel kemampuan pengguna dapat diketahui bahwa dari 32 responden yang diteliti menunjukkan bahwa responden PT. Bukit Megagriya Makmur menyadari akan pentingnya kemampuan pengguna dalam penggunaan SIA pada perusahaan.

\section{Pengaruh Dukungan Manajemen Puncak Terhadap Kinerja SIA}

Hasil analisis penelitian menunjukkan bahwa dukungan manajemen puncak berpengaruh positif dan signifikan terhadap kinerja sistem informasi akuntansi. Hasil analisis regresi linear berganda menunjukan nilai signifikansi kemampuan pengguna sebesar 0,032<0,05. Hasil ini sesuai dengan penelitian Septianingrum (2014), dan 
Muliana, dkk (2017) yang menyatakan dukungan manajemen berpengaruh positif dan signifikan terhadap kinerja sistem informasi akuntansi.

Berdasarkan hasil analisis deskriptif variabel dukungan manajemen puncak dapat diketahui bahwa dari 32 responden yang diteliti, menunjukkan bahwa responden PT. Bukit Megagriya Makmur menyadari akan betapa pentingnya dukungan manajemen puncak dalam penggunaan sistem informasi akuntansi pada perusahaan.

\section{Pengaruh Partisipasi Pengguna Terhadap Kinerja SIA Melalui Pendidikan Dan PelatihanSebagai Variabel Moderasi}

Hasil analisis penelitian menunjukkan bahwa partisipasi pengguna tidak berpengaruh terhadap kinerja sistem informasi akuntansi melalui pendidikan dan pelatihan sebagai variabel moderasi. Hasil analisis regresi moderasi dengan metode nilai selisih mutlak menunjukan nilai signifikansi Moderasi_ $X_{1}$ sebesar $\quad 0,110>0,05$. Berdasarkan hasil penelitian menggambarkan bahwa pendidikan dan pelatihan tidak mampu memperkuat partisipasi pengguna terhadap kinerja sistem informasi akuntansi.

Hasil ini sesuai dengan penelitian Puspitasari dan Juliarsa (2017) yang menyatakan partispasi pengguna tidak berpengaruh terhadap kinerja sistem informasi akuntansi dengan pendidikan dan pelatihan sebagai variabel moderasi.

\section{Pengaruh Kemampuan Pengguna Terhadap Kinerja SIA Melalui Pendidikan Dan Pelatihan Sebagai Variabel Moderasi}

Hasil analisis penelitian menunjukkan bahwa kemampuan pengguna berpengaruh positif dan signifikan terhadap kinerja SIA melalui pendidikan dan pelatihan sebagai variabel moderasi. Hasil analisis regresi moderasi dengan metode nilai selisih mutlak menunjukan nilai signifikansi Moderasi_ $X_{2}$ sebesar $\quad 0,045$. Hal ini menunjukkan bahwa pengguna SIA pada PT. Bukit Megagriya Makmur menyadari akan dampak dari pendidikan dan pelatihan berpengaruh dengan baik pada kemampuan pengguna.

Hasil ini sesuai dengan penelitian Puspitasari dan Juliarsa (2017), Indiranto dan Saputra (2017) yang menyatakan kemampuan pengguna berpengaruh positif dan signifikan terhadap kinerja sistem informasi akuntansi melalui pendidikan dan pelatihan sebagai variabel moderasi.

\section{Pengaruh Dukungan Manajemen Puncak Terhadap Kinerja SIA Melalui Pendidikan Dan Pelatihan Sebagai Variabel Moderasi}

Hasil analisis penelitian menunjukkan bahwa dukungan manajemen puncak tidak berpengaruh terhadap kinerja sistem informasi akuntansi melalui pendidikan dan pelatihan sebagai variabel moderasi. Hasil analisis regresi moderasi dengan 
metode nilai selisih mutlak menunjukan nilai signifikansi Moderasi_ $\mathrm{X}_{3}$ sebesar $0,969>0,05$.

Dari hasil penelitian di atas membuktikan bahwa variabel pendidikan dan pelatihan bukan variabel moderasi antara dukungan manajemen puncak terhadap kinerja SIA. Hal tersebut diduga terjadi karena kurangnya kesiapan manajemen puncak dengan adanya pendidikan dan pelatihan dalam perusahaan, karena minimnya waktu yang tersedia karena adanya pekerjaan di luar kota yang menyebabkan manajemen puncak tidak berada tetap di perusahaan.

Hasil dari penelitian ini tidak mendukung peneliti sebelumnya yang menyatakan bahwa pelatihan dan pendidikan dapat meningkatan sistem informasi yang ada dalam perusahaan dengan adanya pendidikan dan pelatihan.

\section{KESIMPULAN}

Berdasarkan hasil analisis penelitian dan interpretasi maka dapat diambil kesimpulan dalam penelitian ini sebagai berikut :

1. Partisipasi pengguna berpengaruh positif dan signifikan terhadap kinerja SIA. Hal ini berarti bahwa semakin tinggi partisipasi pengguna, maka akan semakin tinggi pula kinerja SIA yang akan dihasilkan pada perusahaan.

2. Kemampuan pengguna berpengaruh positif dan signifikan terhadap kinerja SIA. Hal ini berarti bahwa semakin tinggi kemampuan pengguna, maka akan semakin tinggi pula kinerja SIA yang akan dihasilkan pada perusahaan.

3. Dukungan manajemen puncak berpengaruh positif dan signifikan terhadap kinerja SIA. Hal ini berarti bahwa semakin tinggi dukungan manajemen puncak, maka akan semakin tinggi pula kinerja SIA yang akan dihasilkan pada perusahaan

4. pengguna tidak berpengaruh terhadap kinerja SIA melalui pendidikan dan pelatihan sebagai variabel moderasi.

5. Kemampuan pengguna berpengaruh positif dan signifikan terhadap kinerja SIA melalui pendidikan dan pelatihan sebagai variabel moderasi. Hal ini menunjukkan bahwa pengguna SIA pada PT. Bukit Megagriya Makmur menyadari akan dampak dari pendidikan dan pelatihan.

6. Dukungan manajemen puncak tidak berpengaruh terhadap kinerja sistem informasi akuntansi melalui pendidikan dan pelatihan sebagai variabel moderasi. 


\section{DAFTAR PUSTAKA}

Firdaus, Muhammad. 2019. Ekonometrika Suatu Pendekatan Aplikatif. Edisi Ketiga. Jakarta : Bumi Aksara

Ghozali, Imam.2007.Aplikasi Analisis Multivariate Dengan Program SPSS Universitas Diponegoro, Semarang.

Ghozali, Imam. 2013. Aplikasi Analisis Multivariate dengan Program IBM SPSS 21 Update PLS Regresi. Semarang: Badan Penerbit Universitas Diponegoro.

Ghozali, Imam. 2018. Aplikasi Analisis Multivariate dengan Program IBM SPSS 25. Badan Penerbit Universitas Diponegoro: Semarang.

Hashmi, K. (2004). Introduction and Implementation of Total Quality Management $(T Q M)$. Diambil dari: www.isisigma.com.

Indrianto dan Suputra.2020. Pengaruh Kemampuan Teknik Personal Dan Keterlibatan Pemakai Pada Efektivitas Penggunaan Sia Dengan Pelatihan Sebagai Variabel Pemoderasi. E- Jurnal Akuntansi, 30(8)2053-2064.

Irawan, Prasetya. 2000. Pengembangan Sumber Daya Manusia. Jakarta : STIA- LAN Press.

Jen, Tjhai Fung. 2002. Faktor-Faktor Yang Mempengaruhi Kinerja Sistem Informasi Akuntans. Jurnal Bisnis Dan Akuntansi. Volume IV Nomor 2.

Jogiyanto, H.M. 2005. Analisa dan Desain Sistem Informasi: Pendekatan Terstruktur Teori dan Praktik Aplikasi Bisnis. Yogyakarta : Andi Offset.

Jogiyanto, H.M. 2009. Sistem Teknologi Informasi. Edisi Ketiga.Yogyakarta: Andi Offset

Lee, J.J., dan Kim, S.H. 1992. The Relationship Between Procedural Formalization in MIS Development and MIS Success. Information and Management. 22 (2) pp. 89-111.

Muliana, I kadek. dkk. 2017. Pengaruh Partisipasi Pemakai Sistem Informasi Akuntansi,

Dukungan Manajemen Puncak, Dan Pendidikan Dan Pelatihan Pada Kinerja Sistem Informasi Akuntansi Dengan Kompleksitas Tugas Sebagai Variabel Pemoderasi. 
E-Jurnal Ekonomi Dan Bisnis.Universitas Udayana .6.6 (2017): 2413-2440.

Murray, D. 1990. The Performance Effects Of Participative Budgeting: An Integration Of Intervening And Moderating Variables. Behavior Research In Accounting, 2(2), 104-121.

Prabowo, dkk. 2014. Faktor - Faktor Yang Mempengaruhi Kinerja Sistem Informasi Akuntansi. Accounting Analysis Journal 3 (1) ISSN 2252-6765.

Puspitasari dan Juliarsa. 2017. Keterlibatan Dan Kemampuan Teknik Personal Pada Kinerja Sia Dengan Pendidikan Dan Pelatihan Sebagai VariabelModerasi. EJurnal Akuntansi Universitas Udayana Vol.20.1. Juli (2017): 380-408

Robbins, Stephen dan Timothy A. Judge. 2007. Perilaku Organisasi. Jakarta : PT. Salemba Empat.

Rusmiati, Rusi. 2012. Pengaruh Keterlibatan Pemakai, Kapabilitas Personal Sistem Informasi, Ukuran Organisasi Dan Formalisasi Pengembangan Sistem Informasi Terhadap Kepuasan Pemakai Sistem Informasi Akuntansi. Skripsi, Universitas Pasundan Bandung.

Septianingrum, Putri Aryani.2014. Pengaruh Dukungan Top Management, Kemampuan Pengguna, Serta Adanya Pelatihan Dan Pendidikan Pengguna Terhadap Kinerja Sistem Informasi Akuntansi. Skripsi, Fakultas Ekonomi.Universitas Negeri Yogyakarta.

Soegiharto.2001. Influence Factors Affecting The Performance Of Accounting Information

System. Gajah Mada International Journal Of Business (3:2), May,2001, Pp 177-202.

Sugiyono. 2009. Metode Penelitian Kuantitatif, Kualitatif dan R\&D. Bandung : PT. Alfabeta. Sumarsono, Sonny. 2009. Ekonomi Sumber Daya Manusia Teori dan Kebijakan Publik. Yogyakarta: Graha Ilmu.

Suryawarman dan Sari. 2013. Faktor-Faktor Yang Mempengaruhi Kinerja SistemInformasi

Akuntansi Pada Restoran Waralaba Asing di Kota Denpasar. Jurnal Akuntansi Fakultas Ekonomi Universitas Udayana, 2(1).

Susanto, Azhar. 2008. Sistem Informasi Akuntansi. Jakarta : Gramedia. Susanto, Azhar. 2013. Sistem Informasi Akuntansi. Bandung : Lingga Jaya

Trenida dan Dwirandra. 2018. Dukungan Manajemen Puncak memoderasi Pengaruh 
Keterlibatan Pengguna dan Kemampuan pengguna Pada Kinerja Sistem Informasi Akuntansi. E-Jurnal Akuntansi Universitas Udayana Vol.23.3.Juni (2018): 18441869.

Yulianto, Denny. 2016. Pengaruh Kemampuan, Keterlibatan, Dukungan Manajemen Puncak, Kualitas Sistem Informasi, Dan Kualitas Informasi Terhadap Kinerja Pengguna Sistem Informasi Akuntansi Pada Organisasi Sektor Publik Di Kabupaten Blora. Skripsi, Fakultas Ekonomi Dan Bisnis.Universitas Muhammadiyah Surakarta. 